\title{
GENOTYPE-ENVIRONMENT INTERACTIONS ON THE WEIGHT OF TABAPUA CATTLE IN THE NORTHEAST OF BRAZIL ${ }^{1}$
}

\author{
LAAINA DE ANDRADE SOUZA ${ }^{2 *}$, CARLOS HENRIQUE MENDES MALHADO ${ }^{3}$, JOSÉ BRACCINI NETO $^{4}$, \\ RAIMUNDO MARTINS FILHO ${ }^{5}$, PAULO LUIZ SOUZA CARNEIRO ${ }^{3}$
}

\begin{abstract}
The objective of this work was to verify the presence of genotype-environment interactions (GEI) on the weight adjusted to 365 days of age (W365) for Tabapua cattle in the Northeast of Brazil, using reaction norm (RN) models. The reaction norm model with homogeneous residual variance and 1 -step provided the best fit to the data by the criteria information of deviance, deviance based on the conditional predictive ordinate and deviance based on the Bayes factors. Direct and maternal heritability estimates for the animal model were $0.17 \pm 0.04$ and $0.07 \pm 0.03$, respectively. The direct heritability for model reaction norm in the low and high management environment were $0.21 \pm 0.06$ and $0,70 \pm 0.04$, respectively. The correlations between the slope and intercept of the reaction norm were $0.68 \pm 0.10$ and $0.96 \pm 0.06$ for the direct and maternal effect, indicating that the animals with high genetic values respond positively to environment improvements, especially for the maternal effect. The Spearman correlations between the sire classifications ranged from 0.14 to 0.94 in the different environments and models. Genetic values of most animals were robust to environmental variation, however, considering the sires with the highest number of progeny, there is the presence of GEI.
\end{abstract}

Key words: Environmental gradient. Reaction norms. Random regression. Zebu.

\section{INTERAÇÕES GENÓTIPOS AMBIENTES NO PESO AO ANO DE BOVINOS TABAPUÃ NA REGIÃO NORDESTE DO BRASIL}

\begin{abstract}
RESUMO - Objetivou-se verificar a presença das interações genótipos ambientes (IGA) para o peso ajustado aos 365 dias de idade (P365) na raça Tabapuã na região Nordeste do Brasil usando modelos de normas de reação (NR). O modelo normas de reação com variância residual homogênea e um passo proporcionou melhor ajuste aos dados pelos critérios de informação da deviance, deviance baseada na ordenada preditiva condicional e da deviance baseada nos fatores de Bayes. As estimativas de herdabilidade direta e materna, para o modelo animal, foram $0,17 \pm 0,04$ e $0,07 \pm 0,03$, respectivamente. As herdabilidades diretas para modelo normas de reação no ambiente de baixo e alto manejo foram de $0,21 \pm 0,06$ e $0,70 \pm 0,04$, respectivamente. As correlações entre a inclinação e o intercepto da norma de reação foram de $0,68 \pm 0,10$ e $0,96 \pm 0,06$, para o efeito direto e materno, indicando que os animais com maiores valores genéticos respondem positivamente à melhoria do ambiente, especialmente para o efeito materno. As correlações de Spearman entre as classificações dos reprodutores variaram de 0,14 a 0,94 nos diferentes ambientes e modelos. Os valores genéticos da maioria dos animais apresentam-se robustos à variação ambiental, no entanto quando considera os reprodutores com maior número de filhos, verifica-se a presença de IGA.
\end{abstract}

Palavras-chave: Gradiente ambiental. Normas de reação. Regressão aleatória. Zebuínos.

\footnotetext{
*Corresponding Author

${ }^{1}$ Received for publication in 06/03/2014; accepted in /11/17/2015.

Part from the Thesis on Zootecnics of the first author.

${ }^{2}$ Agricultural, Environmental and Biological Science Center, Universidade Federal do Recôncavo da Bahia, Cruz das Almas, BA, Brazil; laainaandrade@gmail.com.

${ }^{3}$ Department of Biological Science, Universidade Estadual do Sudoeste da Bahia, Jequié, BA, Brazil; carlosmalhado@gmail.com, plscarneiro@gmail.com.

${ }^{4}$ Department of Zootechnics, Universidade Federal do Rio Grande do Sul, Porto Alegre, RS, Brazil; jose.braccini@ufrgs.br.

${ }^{5}$ Faculty of Agronomy, Unifersidade Federal do Cariri, Juazeiro do Norte, CE, Brazil; rmartinsfilho@yahoo.com.br.
} 


\section{INTRODUCTION}

In Brazil, cattle production systems are very heterogeneous due to the large biomes diversity, which is a challenge to the effective definition of selection criteria to assist in the choice of suitable sires to each production system, especially when the genetic evaluation of the herd is carried nationally (NEPOMUCENO et al., 2013).

The genetic merit of an animal can be significantly influenced by changes in the breeding environment, and the progenies of a sire may not repeat the performance of their progenitors if they are raised in a different micro-regions or farms, denoting the need for care when buying sires or semen due to the presence of genotype-environment interactions (GEI). (NOBRE et al., 1987).

GEI exist when the relative merit of two or more genotypes is dependent on the environments in which they are compared (MASCIOLI et al., 2006). According to Streit et al. (2012), if the GEI is disregarded, the predicted genetic values may be biased and the response to selection reduced.

The use of a multi-character approach is a logical choice if the environment may be considered as a distinct variable, however, the use of reaction norms may be more suitable if the environment changes gradually and can be measured on a continuous scale. Thus, there are less parameters to be estimated and there is no need for grouping individuals into different classes (STREIT et al., 2012).

Several authors (AMBROSINI et al., 2012; CARDOSO et al., 2007; CARDOSO; TEMPELMAN, 2012; CORRÊA et al., 2007, 2009; MATTAR et al., 2011; PEGOLO et al., 2011; RODRIGUES 2012; RODRIGUES, 2014; STREIT et al., 2012) have studied GEI through reaction norms (RN). However, there are no studies evaluating this interaction on animals from the Tabapua breed in the Northeast of Brazil, and mainly, including the maternal effect in the valuation model for weight at 365 days of age.

The maternal environment influences the growth of the calf in the pre-birth and post-birth phases, in which the maternal influence can affect the weight of the calf up over one year of age. Biffani et al. (1999) found maternal influence on the weights of calves up to one year of age, and Meyer et al. (1993) found maternal additive genetic effect for weights up to 550 days of age.

Thus, the objective of this work was to verify if there are genotype-environment interactions on the weight fit to 365 days, in animals from the Tabapua breed raised in the Northeast of Brazil, seeking the model that best fits the data of the Tabapua cattle population through reaction norms via Bayesian approach.

\section{MATERIAL AND METHODS}

Records from the Brazilian Association of Zebu Breeders (ABCZ) on the Tabapua breed animals, born between 1975 and 2007 in the Northeast of Brazil, were used. The initial database on weight adjusted to 365 days of age had 26,838 entries, from which 19,078 were excluded $(12,136$ animals with no weight records; 192 disconnected; 266 with measures beyond the established range from $125 \mathrm{~kg}$ to $385 \mathrm{~kg}$; 265 cows under 1.9 and more than 25 years of age; 194 sires under 3 progenies; 3,618 cows under 2 progenies; and 2,407 animals contained in contemporary groups, with less than four observations and average weight above and below +2.5 the standard deviations. Thus, 7,760 records were used for the analyzes.

Contemporary groups $(\mathrm{CG})$ were formed to group animals that had an equivalent production environment, including herd, year, birth season, food regime and gender. Three seasons of birth were used, grouping four months each (season 1: July to October, season 2: November to February, and season 3: March to June). The environmental gradient was set in three classes based on the standardized mean and deviations around that mean: standard deviation of -2.17 (-67), zero e standard deviation of +3.66 (113).

The data set was prepared for reaction norm analysis using routines developed by Cardoso et al. (2008) in SAS language (SAS, 2003). The connection of CG was tested, based on the total number of genetic ties (minimum of 10) using the AMC program (ROSO; SCHENKEL, 2006). The reading of the output of the AMC program and the preparation of the pedigree and data files, consisting only of connected CG were performed. The connectivity of $\mathrm{CG}$ resulted in a main archipelago (CG with more genetic ties and all CG connected to it) with 7,760 animals in $748 \mathrm{CG}$ and 192 animals in 89 CG disconnected. Only data animal from the main archipelago were used.

The INTERGEN program by Cardoso et al. (2008) was used with a standard animal model (AM), this model ignores the GEI and predicts the animal genetic value, and obtain the average estimates of environmental effects based on the CG, which fits as comparison basis for the analysis of reaction norm models.

The Bayes hierarchical models were adjusted using the INTERGEN program with parameters set at structured levels or stages. In the reaction norm models, the genetic value of the animal was found through a function of the medium environmental level related to the CG solution to which the record belongs. A specific genetic value of each animal was

$$
\text { yij }=\mathbf{x i}^{\prime} \boldsymbol{\beta}+\mathrm{Xj}+\mathrm{ai}+\mathrm{mi}+\mathrm{epi}+\mathrm{eij}
$$


predicted for each environmental level according to Cardoso and Tempelman (2012).

Initially, a standard animal model (AM) were used:

In which: $\mathrm{y}_{\mathrm{ij}}=$ animal record (i) in the environment $(\mathrm{j}) ; \beta=$ vector of the fixed effects (linear e quadratic to the cow age); $\mathrm{x}_{\mathrm{i}}{ }^{\prime}=$ incidence vector; $X_{j}=$ random environmental effect of $C G ; a_{i}=$ animal additive genetic value (i); $\mathrm{m}_{\mathrm{i}}=$ animal maternal genetic value (i); ep $_{\mathrm{i}}=$ maternal permanent environmental effect, and $\mathrm{e}_{\mathrm{ij}}=$ random error.

A methodology used to describe the hierarchical reaction norm model (HRNM) was the presupposition of Su et al. (2006), called hierarchical reaction norm model 1-step $\left(\mathrm{HRNM}_{1 \mathrm{~S}}\right)$, which has simultaneous estimation for $\mathrm{CG}$ solutions and the reaction norm $(\mathrm{RN})$ intercept and slope. In this model, the CG effects are considered unknown covariables in the $\mathrm{RN}$ models, in which the environmental effects estimates were used as a covariable to obtain the slope of the RN of the animals,

$\mathrm{y}_{\mathrm{ii}}=\mathbf{x}_{\mathrm{i}}^{\prime} \boldsymbol{\beta}+\mathrm{X}_{\mathrm{j}}+\mathrm{a}_{\mathrm{i}}+\mathrm{m}_{\mathrm{i}}+\mathrm{ep}_{\mathrm{i}}+\mathrm{b}_{1 \mathrm{i}} \mathrm{X}_{\mathrm{j}}+\mathrm{b}_{2 \mathrm{i}} \mathrm{X}_{\mathrm{j}}+\mathrm{e}_{\mathrm{ij}}$

in which ${ }^{X_{j}}$ and $b_{i}$ are together estimated as in the model:

Two different presuppositions were used for the residual variance in the models: (a) homoscedasticity for the AM, HRNM $\left(\mathrm{HRNMHO}_{1 \mathrm{~S}}\right)$, with ei $\sim \mathrm{N}\left(0, \sigma^{2} \mathrm{e}\right)=$ residual variance; e (b) heteroscedasticity for the models $\mathrm{HRNM}_{1 \mathrm{~S}}$ ( $\left.\mathrm{HRNMHE}_{1 \mathrm{~S}}\right)$, com ei $\sim \mathrm{N}\left(0, \sigma^{2}\right.$ eij).

The environmental direct additive and

$$
\begin{aligned}
\sigma_{\mathrm{A}}^{2} \mid \mathrm{X} & =\operatorname{var}\left(\mathrm{a}_{\mathrm{i}}+\mathrm{b}_{1 \mathrm{i}} \mathrm{X}_{\mathrm{j}}\right)=\sigma_{\mathrm{a}}^{2}+\sigma_{\mathrm{b} 1}^{2} \mathrm{x}^{2}+2 \sigma_{\mathrm{a}, \mathrm{b}} \mathrm{x} \\
\sigma_{\mathrm{M}}^{2} \mid \mathrm{X} & =\operatorname{var}\left(\mathrm{a}_{\mathrm{i}}+\mathrm{b}_{2 \mathrm{i}} \mathrm{X}_{\mathrm{i}}\right)=\sigma_{\mathrm{m}}^{2}+\sigma_{\mathrm{b} 2}^{2} \mathrm{x}^{2}+2 \sigma_{\mathrm{a} \cdot \mathrm{b}} \mathrm{x}
\end{aligned}
$$

maternal genetic variances $X,{ }^{\sigma_{M}^{2} \mid X} e^{\sigma_{M}^{2} \mid X}$, were found through:

In which: $\sigma_{\mathrm{a}}^{2}=\sigma_{\mathrm{a}}^{2} \mid \mathrm{X}=$ direct genetic variance component estimates for the intercept of the $\mathrm{RN}, \quad \sigma_{\mathrm{m}}^{2}=\sigma_{\mathrm{m}}^{2} \mid \mathrm{X}=$ maternal genetic variance component estimates for the intercept of the $\mathrm{RN}$, $\sigma_{b}^{z}=\sigma_{b}^{z} \mid X=$ variance component estimates for slope of the additive $\mathrm{RN}$, for slope of the $\mathrm{RN}$ of the animal maternal effects, and $\sigma_{\mathrm{a} b \mathrm{~b}}=$ co-variance component estimates between the intercept and slope.

$$
\begin{aligned}
& \mathrm{h}_{\mathrm{a}}^{2} \mid \mathrm{X}=\frac{\sigma_{\mathrm{a}}^{2} \mid \mathrm{X}}{\sigma_{\mathrm{a}}^{2}\left|\mathrm{X}+\sigma_{\mathrm{m}}^{2}\right| \mathrm{X}+\sigma_{\mathrm{pe}}^{2}+\mathrm{e}_{\mathrm{e}}^{2} \mid \mathrm{X}} \\
& \mathrm{h}_{\mathrm{m}}^{2} \mid \mathrm{X}=\frac{\sigma_{\mathrm{m}}^{2} \mid \mathrm{X}}{\sigma_{\mathrm{a}}^{2}\left|\mathrm{X}+\sigma_{\mathrm{m}}^{2}\right| \mathrm{X}+\sigma_{\mathrm{pe}}^{2}+\mathrm{e}_{\mathrm{e}}^{2} \mid \mathrm{X}}
\end{aligned}
$$

The heritability was estimated through the ratio between the genetic variance and phenotypic variance (genetic + environmental):

In which: $\sigma_{\mathrm{e}}^{2} \mid \mathrm{X}=$ residual variance in the environment $X$, obtained by $\sigma_{\mathrm{e}}^{2} \mid X=\sigma_{\mathrm{e}}^{2} \hat{\eta}^{\mathrm{X}}$ in the heteroscedastic model, and $\sigma_{e}^{2}$ in the homoscedastic model, in which $\eta$ is the heterogeneity parameter variance in the environmental gradient (X), following the model structure proposed by Cardoso et al. (2005).

A Bayesian approach (GIANOLA; FERNANDO, 1986) was used to find the parameter estimates, through the Markov Chain Monte Carlo (MCMC) (Blasco, 2001), adapting the following procedure: a) A sample pilot was used with 55,000 cycles, 5,500 for discarding (burn-in) and 5 for the saving interval (thinning); b) using the variance components saved in a) and the Bayesian Output Analysis packet (BOA) from the $\mathrm{R}$ program (SMITH, 2007), the Raftery and Lewis (1992) test was applied to assess the new size of the chain and the saving period (thinning); and c) discarding period (burn-in) was evaluated under the criteria of Heidelberger and Welch (1983).

Analyzes were performed with the chains that ranged from 330,000 to 440,000 cycles. Means, standard deviations and percentiles $(0.025$ and 0.975$)$ a posteriori of the parameters were obtained from their marginal posterior densities by the KDE Procedure (Kernel Density Estimation) of SAS (SAS, 2003).

The convergence analysis of the chains for the different models was performed using the diagnostic of Geweke (1992), based on Z test for equal means of the logarithm of the conditional distribution of the data, denoted by $l_{i}^{(j)}=\log \mathrm{p}(y \mid \theta$ (j),$\left.M_{\mathrm{i}}\right)$ of the first samples $(10 \%$ initial) and the last part of the Markov chain (last 50\%), similar to that proposed by Brooks and Roberts (1998).

The Spearman correlation was calculated to compare the classification of sires in the animal model (AM) and the hierarchical reaction norm model homoscedastic 1-step $\left(\mathrm{HRNMHO}_{1 \mathrm{~S}}\right)$ according to the environmental gradient. The values were adjusted with mean zero, so zero represents the environment (medium level), with the minimum and maximum amplitudes representing the environmental levels from low to high management in the environmental gradient, respectively.

The following criteria were used to assess the best fit to the model: Deviance Information Criterion (DIC) (SPIEGELHALTER et al., 2002); Deviance based on conditional predictive ordinate (CPO), as described by Gelfand (1996); and deviance criteria based on Bayes factors (BF), described as the deviation based on the estimate of Monte Carlo, proposed by Newton and Raftery (1994). These 
deviations represent the separation level between the evaluated model and a hypothetically perfect fit to the model; and the larger number of criteria with lower values indicates a better fit to the model.

\section{RESULTS AND DISCUSSION}

The results presented were the standard animal model (AM), the hierarchical reaction norm model homoscedastic 1-step $\left(\mathrm{HRNMHO}_{1 \mathrm{~S}}\right)$ and the hierarchical reaction norm model heteroscedastic 1step $\left(\mathrm{HRNMHE}_{1 \mathrm{~S}}\right)$. The $\mathrm{HRNMHO}_{1 \mathrm{~S}}$ presented lower values for $\mathrm{CPO}$ and $\mathrm{BF}$ compared to the
HRNMHE $_{1 \mathrm{~S}}$ (Table 1). The HRNMHO ${ }_{1 \mathrm{~S}}$ model was chosen to present the results discussion because it presented lower values for the adjustment quality evaluators.

Correa et al. (2009), Cardoso et al. (2011), Mattar et al. (2011) and Cardoso Tempelman (2012) used reaction norm models for studies on postweaning weight gain of breeds Angus, Hereford, Canchim and Devon respectively, comparing the HRNM with the AM, and observed that the adjustment was higher for HRNMHO than for HRNMHE models.

Table 1. Deviance information criterion (DIC), deviance based on conditional predictive ordinate (CPO) and deviance based on Bayes factors (BF) for comparison between the standard animal models and hierarchical reaction norm model homoscedastic 1-step $\left(\mathrm{HRNMHO}_{1 \mathrm{~S}}\right)$ and heteroscedastic 1-step (HRNMHE $\left.1 \mathrm{~S}\right)$.

\begin{tabular}{lccc}
\hline Models & DIC & CPO & BF \\
\hline AM & 72566.13 & 73042.19 & 71068.31 \\
HRNMHO $_{1 S}$ & 71794.68 & 73920.86 & 71032.43 \\
HRNMHE $_{1 S}$ & 62340.13 & 74305.51 & 71457.96 \\
\hline
\end{tabular}

The length of Markov chains to the chosen model $\left(\mathrm{HRNMHO}_{1 \mathrm{~S}}\right)$ was at most 440,000 interactions with 44,000 (burn-in) of heating (discard of $10 \%$ ) generating subsequent samples every 44 cycles. The convergence of the chain was assessed by the Geweke test (1992) and the indication of the number of chains, burn-in and saving interval were indicated by the Raftery and Lewis test (1992). A convergence of $5 \%(p>0.05)$ was observed for all parameters in the AM and $\mathrm{HRNMHO}_{1 \mathrm{~S}}$ models within a range between 330,000 and 440,000 cycles.

Cardoso et al. (2011), studying the weight gain at post-weaning of the Hereford breed via reaction norm models, found convergence for all models (standard animal, $\mathrm{HRNMHO}_{2 \mathrm{~S}}, \mathrm{HRNMHO}_{1 \mathrm{~S}}$,
$\mathrm{HRNMHE}_{2 \mathrm{~S}}$ and the HRNMHE $\mathrm{H}_{1 \mathrm{~S}}$ ). Ambrosini et al. (2012) also found a $5 \%$ convergence $(p>0.05)$ for all parameters of the models, for the weight per year in Nelore Mocho in the Northeast of Brazil.

The solutions of the environmental gradient for $\mathrm{HRNMHO}_{1 \mathrm{~S}}$ model ranged from -67 to $113 \mathrm{~kg}$, thus characterizing low and high environment management levels. Direct and maternal heritability estimates for the animal model were $0.17 \pm 0.04$ and $0.07 \pm 0.03$, respectively. The direct heritability for the reaction norm model were $0.21 \pm 0.06$ in the low environment and $0.58 \pm 0.04$ in the high; and the maternal heritability in this model ranged from $0.01 \pm 0.01$ in the low environment and $0.18 \pm 0.07$ in the high (Figure 1).
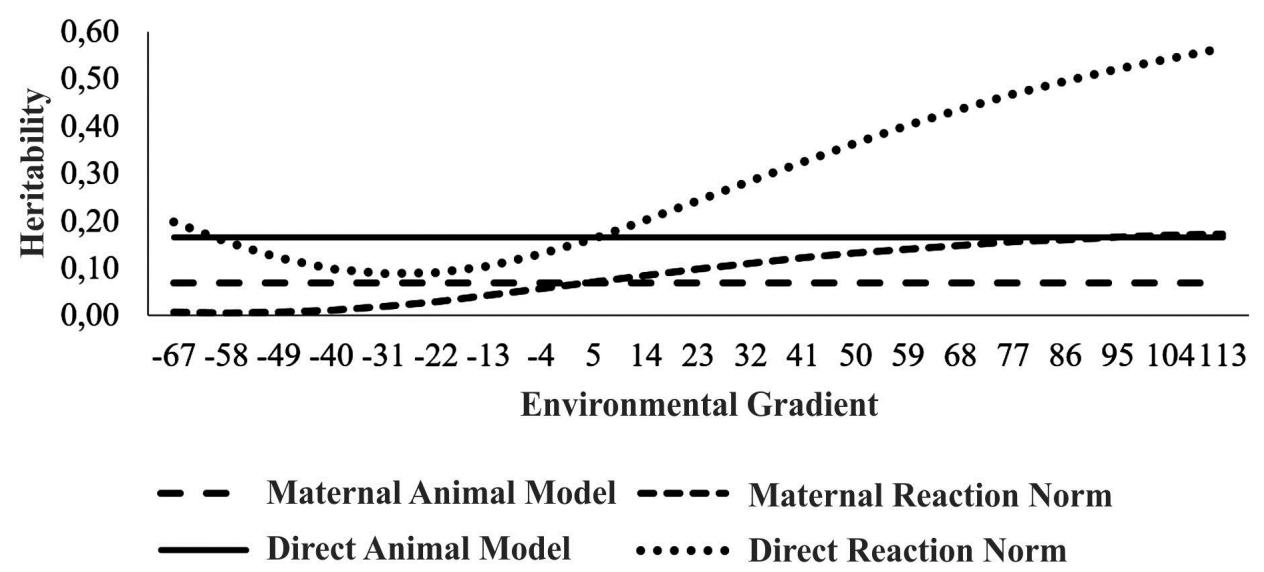

Figure 1. Heritability of the W365 characteristic for the direct and maternal effects in the proposed models.

The wide heritability variation in the environments may be related to the GEI. The high management environments had much higher heritability magnitudes, since the animals could to express all their productive potential, which generate higher genetic variance estimates and the sires could be best discriminated by their genetic values. Grishkavich and Yanai (2013) reported that the 
appearance of the characteristic can change between both genotypes and environments, but the nature of this change can be additive (genotypic and environmental variation). According to these authors, often the environment severely affects the phenotype, which is not an additive effect of the genotype.

Studying GEI characterization and comparing adjustment models for post-weaning weight gain of Devon cattle via reaction norms, Correa et al. 2009 found heritability of $0.13 \pm 0.017$ for the animal model. The heritability increased as environmental gradient improved in the HRNM and HRNMHE, showing that there is a change in the genetic parameters of the population as a function of the environment in which they are, characterizing the presence of GEI. Ambrosini et al. (2012) found an estimated heritability of $0.29 \pm 0.03$ to W365 using an animal model, a value higher than the estimate of $\mathrm{HRNMHO}_{1 \mathrm{~S}}$ at the low environmental level.

The correlations between the slope and the intercept of the reaction norms were $0.68 \pm 0.10$ and $0.96 \pm 0.04$, for the direct and maternal effects, respectively. The medium to high magnitude correlations indicate that animals with higher genetic values for direct and maternal effects respond positively, increasing the estimate of its genetic values in better production environments.

Similar results were found by Mattar et al. (2011) with correlation between intercept and slope of the reaction norm of $0.90 \pm 0.03$, indicating the presence of GEI, characterizing the scale effect (FALCONER and MACKAY, 1996). Ribeiro et al. (2010), evaluating reaction norms on estimation of the environmental sensitivity of the genetic merit for weight at weaning in Nelore cattle, observed that the correlation given by the sample averages a posteriori between the variance component estimates of the intercept and the slope was 0.75, indicating that sensitivity to environmental changes increases as the selection for higher genetic values.

Correa et al. (2009) observed that the genetic correlation between level and slope was $0.83 \pm 0.01$, higher than that reported through the HRNMHE. These correlations indicated that the animals of greater genetic value on the medium environment were also the ones that better responded to the improved environment.

Phenotypic plasticity is any change triggered by the environment, without requiring genetic changes (BRADSHAW, 1965; SCHEINER, 1993; VIA et al., 1995). Robustness and phenotypic plasticity are related to GEI, and if different genotypes have varied reaction norm, there is occurrence of GEI (DE JONG; BIJMA, 2002). Mattar et al. (2009) used a scale that allowed classifying the genotypes according to the slopes of the reaction norms of the animals. These authors found variation from -0.40 to 0.50 levels and observed high incidence of robust and medium genotypes $(13,968$ animals $)$ with slopes between -0.20 and 0.20 .

The slopes of the reaction norms ranged from -0.45 to +0.45 (direct effect), in which $96.37 \%$ of the animals varied between -0.20 and +0.20 , characterized as robust genotype; and $3.63 \%$ below -0.20 and above +0.20 , characterized as plastics genotypes. The change for the maternal effect was -0.20 to +0.24 , observing almost all of the robust genotype animals.

Considering the 10 sires with the highest number of progeny (Figures 2 and 3), animals with plastic genotypes and changes on the slopes were observed, which indicates presence of GEI with scale effect and, in some cases, changes in classification over the environmental gradient. This is relevant, since the animals used intensively may be chosen wrongly, depending on the environment in which their progeny will be raised.

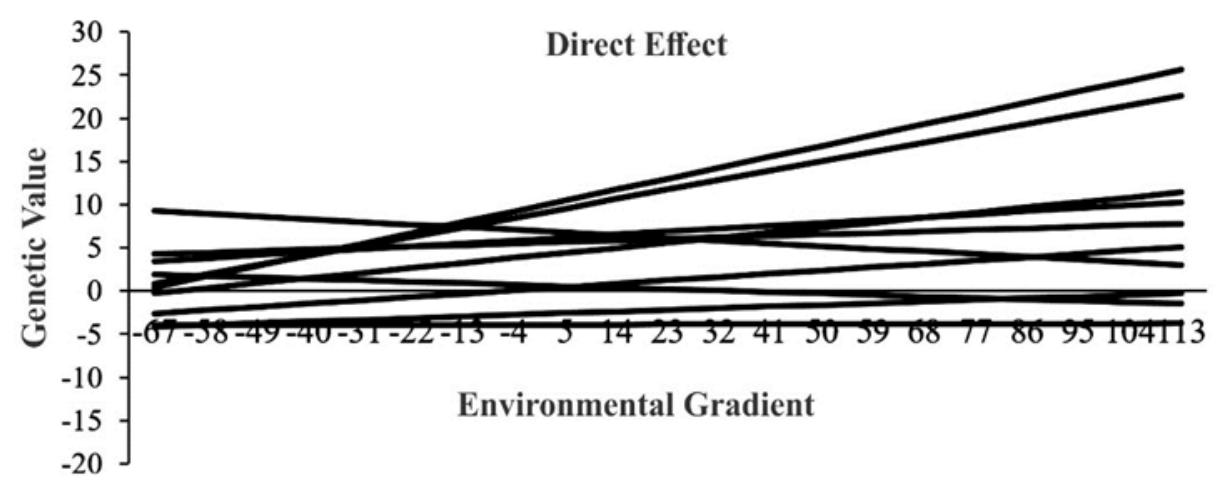

Figure 2. Reaction norm over the environmental gradient to W365 for direct effect found for the 10 sires with the highest number of progeny. 


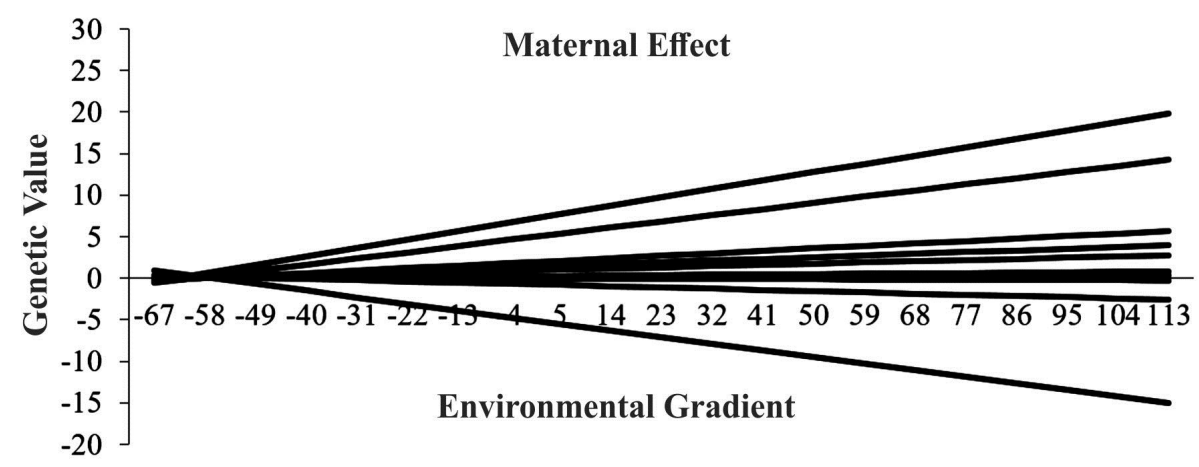

Figure 3. Reaction norm over the environmental gradient to W365 for maternal effect found for the 10 sires with the highest number of progeny.

Ambrosini et al. (2012) found slope of the reaction norms ranging from -0.80 to 0.67 . Most animals $(80.96 \%)$ were classified as robust and medium with slopes between -0.20 and 0.20 . Plastic genotypes were observed only for $19.03 \%$ of the animals of the kinship matrix.

The Spearman correlation between the sire classifications ranged from -0.35 to 0.95 in the different environments and models (Table 2).

The correlation between the AM and HRNM (medium and high levels), considering all the sires, were high, indicating that the AM selects animals that can be used in these environments but not in low management environment, common in the Northeast of Brazil. Correlations between $\mathrm{HRNMHO}_{1 \mathrm{~S}}$ (medium level) with $\mathrm{HRNMHO}_{1 \mathrm{~s}}$ (high level) were also high. The other low correlations (positive and negative) indicate that selection in an environment does not necessarily imply genetic gain in the other. The selection of animals in the medium and high management environments will not result in gain if they are used in low management environments.

Table 2. Spearman correlations between the classifications of Tabapua sires in the Northeast of Brazil, found for the animal model (AM) and the hierarchical reaction norm model homoscedastic 1-step $\left(\mathrm{HRNMHO}_{1 \mathrm{~S}}\right)$ for the different environmental levels.

\begin{tabular}{|c|c|c|c|c|c|c|}
\hline \multirow{2}{*}{$\begin{array}{l}\text { Models } \\
\text { AM }\end{array}$} & \multicolumn{2}{|c|}{ HRNMHO $_{1 \mathrm{~S}}$ (Low) } & \multicolumn{2}{|c|}{ HRNMHO $_{1 \mathrm{~S}}$ (Medium) } & \multicolumn{2}{|c|}{ HRNMHO $_{1 \mathrm{~S}}$ (High) } \\
\hline & 0.1416 & $(0.0375)$ & 0.9519 & $(0.0001)$ & 0.8162 & $(0.0007)$ \\
\hline HRNMHO $_{1 \mathrm{~S}}$ (Low) & & & -0.0513 & $(0.4531)$ & -0.3549 & $(0.0001)$ \\
\hline HRNMHO $_{1 \mathrm{~S}}$ (Medium) & & & & & 0.9362 & $(0.0001)$ \\
\hline
\end{tabular}

Numbers between parentheses $=p$-value

Correa et al. (2010) found similar results, with Spearman correlation between classifications ranging from 0.12 to 0.99 , considered a moderate to high ordering change. They stated that these results indicate the need to consider the GEI in the selection process, especially in low individual performance levels conditions, in which most of ordering inversions were found. However, scale effect was observed in the high performance levels, therefore, the higher average genetic value individuals were the ones that better responded to environmental changes.

Mattar et al. (2011) evaluated GEI for weight per year in cattle Canchim via reaction norms and observed high Spearman correlations, with values greater than 0.90 compared to the animal model, with HRNMHO in three levels (low, medium and high).

Ambrosini et al. (2012) observed that the Spearman correlations between sire classifications with greater genetic value ranged from 0.73 to 0.99 in the different environments and models when the $5 \%$ of sires with the highest genetic values were chosen, and 0.71 to 0.99 when $10 \%$ of these sires were chosen. The lower correlations were observed in the animal model compared to reaction norm models, confirming the presence of GEI.

The correlations between the genetic values of the sires in the different environmental gradients ranged from -0.61 to 1.00 for the direct effect, and from -0.41 to 1.00 for the maternal effect on the $\mathrm{HRNMHO}_{1 \mathrm{~S}}$. (Figures 4 and 5). 


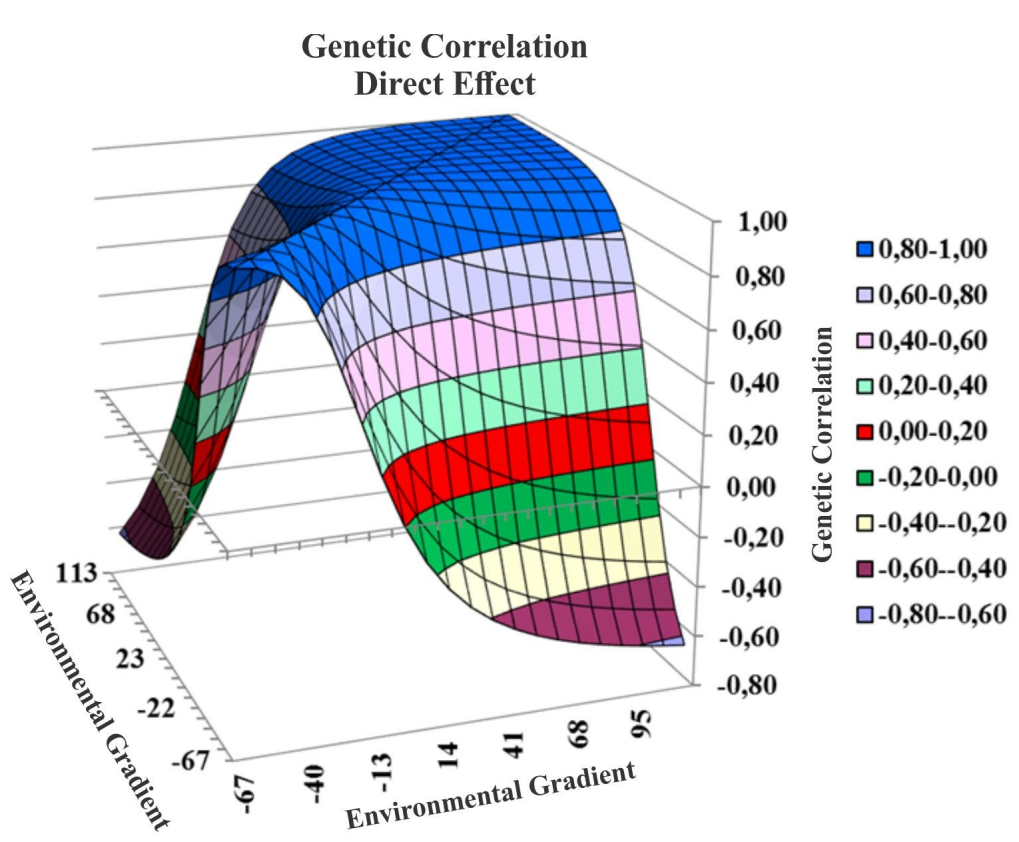

Figure 4. Surface graph of response of correlations between direct genetic values and environmental gradient.

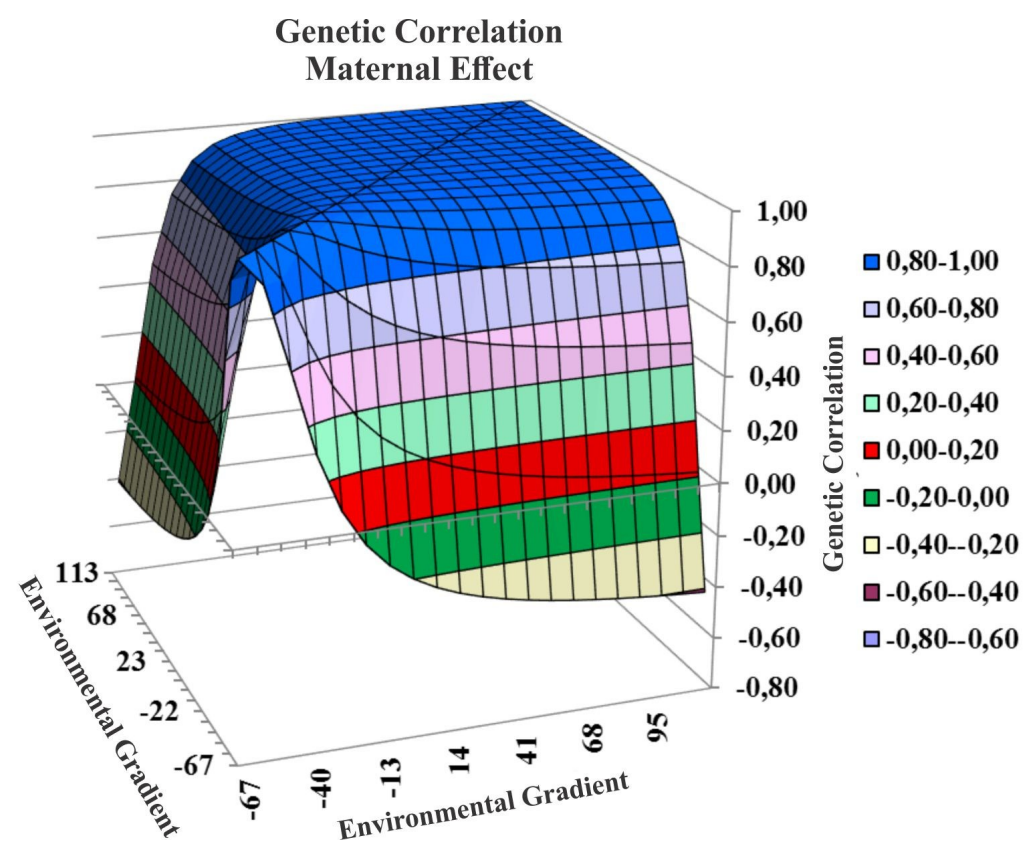

Figure 5. Surface graph of response of correlations between maternal genetic values and environmental gradient.

The Figures 4 and 5 show that the genetic correlation in the medium and high values of the environmental gradient is highly positive, greater than 0.80 , however, this correlation decreases as the environment is unfavorable, with negative values between the extremities of the environmental gradient. These results agree with those found by Correa et al. (2009), who stated that the genetic required for production in very adverse environments is different from that which best produces in reasonable and good environments.

Ambrosini et al. (2012) found correlations between genetic values in the environmental gradient with little difference for the $\mathrm{HRNMHO}_{1 \mathrm{~s}}(0.78$ to 1.00). Regarding the 2-step model, which was the second best model of the study, the correlations showed higher variation (0.50 to 1.00$)$, indicating that there may be GEI.

\section{CONCLUSIONS}

The reaction norm model 1-step, which consider the homogeneity of residual variance, is the one that best fits the data in the population of Tabapua cattle of the Northeast of Brazil. Genetic 
values of most animals were robust to the environmental variation. However, considering the sires with the highest number of progeny, the presence of GEI is observed.

\section{ACKNOWLEDGEMENTS}

To the Coordination for the Improvement of Higher Education Personnel (CAPES) for granting the scholarship, the National Council for Scientific and Technological Development $(\mathrm{CNPq})$ and the Research Support Foundation of the State of Bahia (Fapesb) for their support and financial resources.

\section{REFERENCES}

AMBROSINI, D. P. Interação genótipos ambientes em bovinos da raça Nelore Mocha na Região Nordeste do Brasil obtido por normas de reação. 2012. 81f. Dissertação (Mestrado em Zootecnia: Área de Concentração em Produção de Ruminantes) - Universidade Estadual do Sudoeste da Bahia, Itapetinga, 2012a.

AMBROSINI, D. P. et al. Interação genótipo $\times$ ambiente quanto ao peso ao ano em bovinos Nelore Mocho no Nordeste do Brasil. Pesquisa Agropecuária Brasileira, Brasília, v. 47, n. 10, p. 1489-1495, 2012.

BIFFANI, S.; MARTINS FILHO, R.; GIORGETTI, A. Fatores ambientais e genéticos sobre o crescimento ao ano e ao sobre ano de bovinos nelore, criados no Nordeste do Brasil. Revista Brasileira de Zootecnia, Brasília, v. 28, n. 3, p. 468-472, 1999.

BLASCO, A. The Bayesian controversy in animal breeding. Journal of Animal Science, Champaign, v. 79, n. 8, p. 2023-2046, 2001.

BRADSHAW, A. D. Evolutionary significance of phenotypic plasticity in plants. Advances in genetics, New York, v. 13, n.21, p. 115-155, 1965.

BROOKS, S. P.; ROBERTS, G. O. Convergence assessment techniques for Markov chain Monte Carlo. Statistics and Computing, Norwell, 8, n. 4, p. 319-335, 1998.

CARDOSO, F. F.; ROSA, G. J. M.; TEMPELMAN, R. J. Multiple-breed genetic inference using heavytailed structural models for heterogeneous residual variances. Journal of Animal Science, Champaign, v. 83, n. 8, p. 1766-1779, 2005.

CARDOSO, F. F. Manual de utilização do programa Intergen - versão 1.0 em estudos de genética quantitativa animal. ed. Bagé: Embrapa Pecuária Sul, 2008. 74 p. (Série Documentos, 74).

CARDOSO, F. F.; OLIVEIRA, M. M.; CAMPOS, L. T. Modelos hierárquicos Bayesianos para estudo de interação genótipo-ambiente via normas de reação aplicados ao ganho pós-desmama de bovinos Angus. In: Reunião Anual da Sociedade Brasileira de Zootecnia, 44., 2007, Jaboticabal. Anais... Jaboticabal: UNESP, 2007. p. 608-610.

CARDOSO, F. F.; TEMPELMAN, R. J. Linear reaction norm models for genetic merit prediction of Angus cattle under genotype by environment interaction. Journal of Animal Science, Champaign, v. 90, p. 2130-2141, 2012.

CARDOSO, L. L. et al. Hierarchical Bayesian models for genotype $\times$ environment estimates in post -weaning gain of Hereford bovine via reaction norms. Revista Brasileira de Zootecnia, Brasília, v. 40, n. 2, p. 294-300, 2011.

CORRÊA, M. B. B. Caracterização da interação genótipo-ambiente no desempenho de bovinos Devon no Rio Grande do Sul via normas de reação obtidas por regressão aleatória. Pelotas. 2007. 87 f. Tese (Doutorado em Ciências: Área de Concentração em Melhoramento Animal) Universidade Federal de Pelotas, Pelotas, 2007.

CORRÊA, M. B. B; DIONELlO, N. J. L.; CARDOSO, F. F. Caracterização da interação genótipo-ambiente e comparação entre modelos para ajuste do ganho pós-desmama de bovinos Devon via normas de reação. Revista Brasileira de Zootecnia, Brasília, v. 38, n. 8, p. 1468-1477, 2009.

CORRÊA, M. B. B.; DIONELLO, N. J. L.; CARDOSO, F. F. Genetic evaluation of Devon cattle using a reaction norms model. Revista Brasileira de Zootecnia, Brasília, v. 39, n.1, p.128-133, 2010.

DE JONG, G.; BIJMA, P. Selection and phenotypic plasticity in evolutionary biology and animal breeding. Livestock Production Science, Shannon, v. 78, n.3, p. 195-214, 2002.

FALCONER, D. S.; MACKAY, T. F. C. Introduction to Quantitative Genetics. 4 ed. Essex, U. K.: Longman Group Ltd,. 1996. 464 p.

GELFAND, A. E. Model determination using sampling-based methods. In W. R. Gilksand S. Richardson and D. J. Spiegelhalter (Eds.). Markov Chain Monte Carlo inpractice. London: Champman \& Hall, 1996. v.1, p. 145-161.

GEWEKE, J. Evaluating the accuracy of sampling -based approaches to the calculation of posterior 
moments. In: BERNARDO, J. M. et al. (Eds.). Bayesian statistics. New York: Oxford University, 1982. p. 526.

GIANOLA, D.; FERNANDO, R. L. Bayesian methods in animal breeding theory. Journal of Animal Science, Savoy, v. 63, n. 1, p. 217- 244, 1986.

GRISHKEVICH, V.; YANAI, I. The genomic determinants of genotype $\times$ environment interactions in gene expression. Trends in Genetics, Berkeley, v. 29, n. 8, p. 479- 487, 2013.

HEIDELBERGER, P.; WELCH, P. Simulation run length control in the presence of an initial transient. Operations Research, Catonsville, v.31 n.6, p.11091144, 1983.

MASCIOLI, A. S. et al. Estudo da interação genótipo $\mathrm{x}$ ambiente sobre características de crescimento de bovinos de corte utilizando Inferência Bayesiana. Revista Brasileira de Zootecnia, Brasília, v. 35, n. 6, p. 2275-2284, 2006.

MATTAR, M.; C.; CARDOSO, F. F.; ALENCAR, M. M. Plasticidade fenotípica e heterogeneidade de variâncias para o peso ao sobreano de bovinos Canchim via normas de reação. In: Reunião Anual da Sociedade Brasileira de Zootecnia, 46., 2009, Maringá. Anais...Maringá: Embrapa Pecuária Sudeste, 2009.p. 1-3.

MATTAR, M. et al. Genotype $\times$ environment interaction for long-yearling weight in Canchim cattle quantified by reaction norm analysis. Journal Animal Science, Champaign, v. 89, n.8, p. 23492355, 2011.

MEYER, K.; CARRICK, M. J.; DONNELLY, B. J. P. Genetic parameters for growth traits of Australian beef cattle from a multbreed selection experiment. Journal Animal Science, Champaign, v.71, n.1, p.2614-2622, 1993.

NEPOMUCENO, L. L. et al. Interação genótipoambiente para características sob efeito maternal na raça Nelore nos estados do Maranhão, Mato Grosso e Pará. Revista Brasileira Saúde Produção Animal, v. 14, n.2, p. 269-276, 2013.

NEWTON, M.A.; RAFTERY, A.E. Approximate Bayesian inference by the weighted likelihood bootstrap (with Discussion). Journal of the Royal Statistical Society, v. 56, n.1, p. 3-48, 1994.

NOBRE, P. R. C.; ROSA, A. N.; EUCLIDES FILHO, K. Interação genótipo $\mathrm{x}$ ambiente em gado nelore. Revista da Sociedade Brasileira de Zootecnia, Brasília, v. 16, n. 4, p. 352-363, 1987.
PEGOLO, N. T. et al. Effects of sex and age on genotype $\mathrm{x}$ environment interaction for beef cattle body weigth studied using reaction norm models. Journal of Animal Science, Champaign, v. 89, n. 11 , p. $3410-3425,2011$

RAFTERY, A. E.; LEWIS, S. M. One long run with diagnostics: Implementation strategies for Markov Chain Monte Carlo. Statistic Science, Durham, v. 7, n.4, p 493-497, 1992.

RIBEIRO, S. et al. Normas de reação na estimação da sensibilidade ambiental do mérito genético para peso à desmama em bovinos. In: Simpósio Brasileiro de Melhoramento Animal, VIII., 2010, Maringá. Anais... Maringá: UEM, 2010. p. 1-3.

RODRIGUES, D. T. Interação genótipos ambientes em animais via modelos de normas de reação. 2012. 86 f. Dissertação (Mestrado em Estatística Aplicada e Biometria: Área de Concentração em Estatística Aplicada e Biometria) Universidade Federal de Viçosa, Viçosa, 2012.

RODRIGUES, F. B. Interação genótipos ambientes em bubalinos (BubalusBubalis) da raça mediterrâneo via normas de reação. 2014. 60 f. Tese (Doutorado em Zootecnia: Área de Concentração Produção de Ruminantes) Universidade Estadual do Sudoeste da Bahia, Itapetinga, 2014

ROSO, V. M.; SHENKEL, F. S. AMC - A computer program to assess the degree of connectedness among contemporary groups. In: World Congress on Genetics Applied to Livestock Production, 8., 2006, Belo Horizonte. Anais...Belo Horizonte: UFMG, 2006. p. 27-26. 2006.

SAS INSTITUTE INC. SAS/STAT. SAS Institute Inc. 2003.

SCHEINER, S. M. Genetics and evolution of phenotypic plasticity. Annual Review of Ecologic Systens, Palo Alto, v. 24, n.1, p. 35-68, 1993.

SMITH, B. J. Bayesian output analysis program (BOA) version 1.1.7.2 User's manual. Iowa: University Of Iowa., 2007.

SPIEGELHALTER, D. J.; BEST, N. G. et al. Bayesian measures of model complexity and fit. Journal Of The Royal Statistical Society Series BStatistical Methodology, Malden, v. 64, n.4, p. 583616. 2002

STREIT, M. et al. Reaction norms and genotype-byenvironment interaction in the German Holstein dairy cattle. Journal of Animal Breeding and Genetics, Malden, v. 129, n.5, p. 380-389. 2012. 
SU, G. et al. Bayesian analysis of the linear reaction norm model with unknown covariates. Journal Animal Science, Champaign, v. 84, n.7, p. $1651-1657,2006$.

VIA, S. et al. Adaptive phenotypic plasticity: consensus and controversy. Trends in Ecology and Evolution, Amsterdam, v. 10, n.5, p. 212- 217, 1995. 